\title{
Pengaruh Service Excellence terhadap Brand Equity pada Pelanggan Batik Air
}

\author{
Ryan Hidayat \\ Prodi IImu Komunikasi FISIP Universitas Muhammadiyah Tangerang \\ Email: bagas.better@gmail.com \\ Abdul Basit \\ Prodi IImu Komunikasi FISIP Universitas Muhammadiyah Tangerang \\ Email: basit.umt@gmail.com
}

\begin{abstract}
ABSTRAK
Penelitian ini bertujuan untuk: (1) mengetahui seberapa besar pengaruh pelayanan prima terhadap ekuitas nilai dalam benak pelanggan Batik Air; (2) mengetahui seberapa besar pengaruh ekuitas nilai di dalam benak pelanggan Batik Air; dan (3) mengetahui seberapa besar pengaruh pelayanan prima di dalam benak para pelanggan Batik Airlines. Penelitian ini menggunakan pendekatan kuantitatif. Sebagai penelitian deskriptif dan menggunakan causal explanations, populasi dalam penelitian ini ialah pelanggan Batik Air yang berada di ruang tunggu keberangkatan domestik pada Terminal 1C Bandar Udara Internasional SoekarnoHatta Jakarta. Jumlah respoden dalam penelitian ini adalah sebanyak 91 orang dari keseluruhan populasi (978 orang). Data penelitian diperoleh melalui wawancara dan kuesioner. Hasil penelitian ini menunjukkan bahwa pelayanan prima memiliki pengaruh yang signifikan terhadap ekuitas nilai. Pelayanan prima yang diterapkan maskapai Batik Air di Bandar Udara Internasional Soekarno-Hatta berada pada kategori tinggi. Penilaian tertinggi ada pada dimensi empati, sementara penilaian terendahnya berada pada dimensi daya tanggap. Koefisien determinasi yang diperoleh angka $R^{2}$ adalah sebesar 0,575 atau $(57,5 \%)$ yang menunjukkan persentase sumbangan pengaruh variabel independen $\left(X_{1}-X_{5}\right)$ terhadap variabel dependen ekuitas nilai adalah sebesar $57,5 \%$, sementara sisanya sebesar $42,5 \%$ dipengaruhi oleh variabel lainnya yang tak diserrakan dalam penelitian ini.
\end{abstract}

Kata Kunci: Service excellence, brand equity, kesadaran merek, kepuasan pelanggan, Batik Air

\begin{abstract}
This study aims to: (1) determine the influence of excellent service toward value equity in customer mind of Batik Air; (2) determine the influence of value equity in customer's mind Batik Air; and (3) determine the influence of excellent service in the minds of Batik Airlines's customers. This study uses a quantitative approach. As a descriptive study and using causal explanations, the population in this study is Batik Air customers in domestic departure lounge at Terminal 1C Soekarno-Hatta International Airport. The number of respondents in this study was 91 people from the total population (978 people). Research data obtained through interviews and questionnaires. The results of this study indicate that excellent service has significant influence on value equity. Excellent service applied by Batik Air airline at Soekarno-Hatta International Airport is in high category. The highest scores are in the empathy dimension, while responsiveness dimension has lowest rating. The coefficient of determination obtained by $R 2$ is equal to 0,575 (57,5\%) which show the percentage contribution of independent variable (X1-X5) to dependent variable equity value is $57,5 \%$, while the rest $(42,5 \%)$ ia influenced by others variable that not included in this study.
\end{abstract}

Keywords: Service excellence, brand equity, brand awareness, consumer satisfaction, Batik Air

Citation : Hidayat, Ryan dan Abdul Basit. (2018). "Pengaruh Service Excellence terhadap Brand Equity pada Pelanggan Batik Air". Nyimak Journal of Communication, 2(1): 17-35. 


\section{PENDAHULUAN}

Dalam upaya menghadapi persaingan yang makin ketat di era perdagangan bebas, salah satu aspek yang menjadi perhatian atau fokus utama maskapai penerbangan adalah memperbaiki kualitas layanan serta sekaligus meningkatkannya. Upaya ini menjadi makin penting di tengah pertumbuhan jumlah penumpang angkutan udara yang meningkat pesat. Selain berperan sebagai simpul dalam jaringan transportasi sesuai dengan hierarkinya, bandar udara juga berperan sebagai pintu gerbang bagi kegiatan ekonomi, tempat kegiatan alih moda transportasi, pendorong (penunjang) kegiatan industri atau perdagangan, pembuka isolasi daerah, pembangunan daerah terbatas, dan lain sebagainya.

Dalam bisnis jasa yang didasarkan pada kepercayaan dan ketepatan waktu, permasalahan kualitas pelayanan dan kenyamanan merupakan faktor menentukan dalam keberhasilan suatu maskapai penerbangan. Dengan berbagai strategi, setiap maskapai penerbangan pun berlomba-lomba meraih kepercayaan pelanggan untuk menghasilkan profit yang maksimal, salah satunya dengan meningkatkan layanan prima (service excellences) terhadap para pelanggannya (Azmarani, 2016; Saleki, 2017; Lestari, 2015; Widjaja, Aprilia \& Harianto, 2017).

Sebagai anak perusahaan dari Lion Group, Batik Air merupakan maskapai yang berhasil mendapat tingkat ketepatan waktu atau on time performance (OTP) yang baik di Indonesia. Maskapai yang mulai beroperasi sejak Mei 2013 ini, Batik Air meraih presentase OTP sebesar 93\% dengan jumlah penerbangan tepat waktu sebanyak 37.798 penerbangan dari 40.690 penerbangan domestik periode Januari-Desember 2015. Bahkan, pada 2017, Batik Air berhasil memperoleh urutan ketiga Sebagai maskapai berjadwal nasional Indonesia yang mempunyai ketepatan waktu terbang cukup baik dengan OTP 88,66\% (di atas 85\%) (Senja, 2018). Adapun dua posisi sebelumnya ditempati oleh NAM Air yang mencatatkan OTP 92,62\% serta Sriwijaya Air dengan OTP 88,69\%. Setelah Batik Air, posisi selanjutnya berturut-turut ditempati oleh Garuda Indonesia, Citilink, Indonesia AirAsia Extra, Indonesia AirAsia, Travel Express, Susi Air, TransNusa, Lion Mentari, Wings Air, Kalstar Aviation, (berhenti operasi per 30 September 2017), dan Trigana Air.

Pada 2017 sendiri, Direktorat Angkutan Udara Ditjen Perhubungan Udara Kementerian Perhubungan (Kemenhub) mencatat jika penerbangan rute domestik maskapai nasional (Januari-Desember) ada sebanyak 828.608 penerbangan. Angka tersebut menunjukkan adanya peningkatan sebanyak 8,5\% jika dibandingkan pada 2016 dengan jumlah 763.522 penerbangan. Sementara itu, untuk tingkat ketepatan waktu operasional (OTP) maskapai penerbangan pada 2017 sebanyak 80,14\% atau 664.024 penerbangan tepat waktu dari total 828.609 penerbangan yang dilakukan (dalam Senja, 2018). 
Sebagai maskapai yang berhasil memperoleh predikat baik dalam hal OTP (peringkat ketiga pada 2017) Batik Air mengusung slogan "Journer Begins" guna menumbuhkan kesadaran merek dalam benak konsumennya. Lion Group berusaha keras untuk menumbuhkan kesan bahwa Batik Air adalah maskapai penerbangan yang trendi, dengan ciri khas badan pesawat bermotif batik beserta gaya dan warna baru yang membuat para penggunanya merasa lebih percaya diri lantaran ciri khas tersebut seakan-akan ingin mempromosikan salah satu identitas budaya Indonesia.

Tiga konsep yang diusung oleh Batik Air adalah (1) Menyediakan layanan transportasi udara yang nyaman, konsisten, dan handal; (2) Untuk pasar domestik, Batik Air memberikan fleksibelitas bepergian dan value for money dengan pilihan banyak untuk pelanggan; dan (3) Untuk pasar internasional memberi kenyamanan berpergian dengan layanan khas Batik. Selain karena merupakan anak perusahaan dari Lion Group yang sudah memiliki citra baik di mata konsumen, dengan ketiga konsep yang diusung tersebut Batik Air hendak menyampaikan kepada pelanggan sebagai maskapai penerbangan berkualitas. Hal ini juga telah dibuktikan Batik Air yang berhasil meraih penghargaan karena mendapat tingkat ketepatan waktu atau on time performance (OTP) yang baik serta menyediakan pelayanan yang berbasis full service arilines. Karena itu, dapat dikatakan bahwa Batik Air bukanlah merek (brand) yang diragukan lagi di mata pelanggannya, dan kesemuanya ialah sebuah upaya guna menciptakan kesadaran merek (brand) di dalam benak pelanggannya.

Upaya penciptaan kesadaran merek itu sendiri merupakan hal yang penting guna membedakan suatu produk dengan kompetitornya. Dengan adanya kesadaran merek dalam benak konsumen, konsumen diharapkan dapat lebih memahami akan arti merek (brand). Bagi produsen merek juga berperan penting guna menciptakan asosiasi dan makna unik (diferensiasi), sarana keunggulan kompetitif, dan sumber financial returns. Sementara bagi konsumen merek memiliki peranan penting bagi identifikasi sumber produk, penetapan tanggung jawab pada produsen/distributor spesifik, pengurang resiko, penekanan biaya pencarian internal dan eksternal, janji atau ikatan khusus dengan produsen, alat simbolis yang memproyeksikan citra diri dan signal kualitas (Tjiptono, 2015).

Menurut Aaker (dalam Rangkuti, 2009), kesadaran merek memperlihatkan kesanggupan calon pembeli guna mengenali atau mengingat kembali bahwa suatu merek adalah bagian dari kategori produk tertentu. Adapun pengukuran kesadaran bisa diukur berdasarkan tiga tingkat: (1) puncak pikiran; (2) pengingatan kembali; (3) pengenalan merek; dan (4) tidak menyadari merek. Sementara itu, kesan-kesan tentang merek akan semakin meningkat dengan banyaknya pengalaman konsumen dalam mengonsumsi suatu merek atau dengan semakin sering penampakan merek tersebut dalam strategi komunikasi. Karena itu, mereka 
(brand) yang telah mapan mempunyai posisi kuat dalam persaingan apabila didukung oleh asosiasi- asosiasi yang kuat. Asosiasi-asosiasi merek yang saling berkaitan akan menimbulkan suatu rangkaian yang disebut brand image serta menjadi pijakan untuk konsumen dalam keputusan pembelian dan loyalitasnya pada merek tersebut.

Berdasarkan penjelasan tersebut di atas, penelitian ini bertujuan untuk: (1) mengetahui seberapa besar pengaruh pelayanan prima terhadap ekuitas nilai dalam benak pelanggan Batik Air; (2) mengetahui seberapa besar pengaruh ekuitas nilai di dalam benak pelanggan Batik Air; dan (3) mengetahui seberapa besar pengaruh pelayanan prima di dalam benak para pelanggan Batik Airlines.

\section{KERANGKA TEORI}

\section{Pelayanan Prima (Service Excellence)}

Pelayanan prima ialah kemampuan perusahaan dalam memberikan layanan sesuai dengan standar yang ditetapkan untuk memaksimalkan kepuasan pelanggan Pelayanan prima didefinisikan sebagai teknik untuk menganilisis jurang/gap yang terjadi pada performa kualitas pelayanan perusahaan/organisasi dengan kebutuhan kualitas pelayanan pelanggan. Selain memberikan kepuasan pelanggan, pelayanan prima bertujuan memberi kepercayaan bagi pelanggan, menjaga pelanggan merasa diperhatikan akan kebutuhan dan keinginannya, serta menjaga dan menumbuhkan loyalitas pelanggan (Rahmayanti, 2014: 18).

Menurut Tjiptono (2015: 77), standar pelayanan prima mencakup 5 aspek, yaitu tangible, realibility, responsiviness, assurance dan emphaty. Bukti fisik atau tangible adalah wujud fisik yang ditampilkan yang terdiri atas peralatan, fasilitas, penampilan personil, dan materi komunikasi. Keandalan (reliability) adalah suatu kemampuan untuk memberi layanan secara andal, sesuai dengan yang dijanjikan, menepati promosi dan menangani masalah yang dialami pelanggan. Daya tanggap (responisiveness) merupakan kesigapan karyawan dalam hal membantu pelanggan, menjawab pertanyaan pelanggan, dan memberi pelayanan dengan segera. Jaminan (assurance) merupakan pengetahuan serta kemampuan karyawan dalam memberi jaminan pelayanan pada pelanggan, meliputi kompetensi, kesopanan, kredibilitas, dan keamanan. Empati (emphaty) merupakan pengungkapan kepedulian terhadap pelanggan, yang meliputi pemberian kemudahan akses, komunikasi, dan perhatian terhadap pelanggan.

Sementara itu, pelayanan prima memiliki empat tujuan dalam membangun hubungan dengan pelanggan: (1) mencegah pembelotan serta membantu kesetiaan pelanggan (customer loyality); (2) memberikan rasa puas dan kepercayaan kepada konsumen; (3) menjaga supaya pelanggan merasa diperhatikan serta dipentingkan segala kebutuhan dan 
keinginannya; (4) upaya mempertahankan pelanggan supaya tetap loyal dalam menggunakan produk atau jasa yang ditawarkan (Rahmayanti, 2013: 17).

\section{Kepuasan Pelanggan}

Menurut Tjiptono (2015: 78-83), terdapat lima teori yang sering digunakan sebagai acuan pada riset kepuasan pelanggan.

\section{Expentancy Disconfirmation Model}

Model yang dikembangkan pada dekade 1970-an ini mendefinisikan kepuasan pelanggan sebagai evaluasi yang memberikan hasil di mana pengalaman yang dirasakan setidaknya sama baiknya (sesuai) dengan diharapkan. Berdasarkan konsumsi atau pemakaian produk atau merek tertentu dan juga merek lainnya dalam kelas produk yang sama, pelanggan membentuk harapannya mengenai kinerja seharusnya dari merek yang bersangkutan. Harapan atas kinerja ini lalu dibandingkan dengan kinerja aktual produk (persepsi terhadap kualitas produk atau jasa). Jika kinerja lebih lebih rendah daripada harapan, yang terjadi ialah ketidakpuasan emosional (negatif disconfirmation), dan jika kinerja cenderung lebih besar dibanding harapan, yang terjadi adalah kepuasan emosional (positif disconfirmation). Apabila kinerja sama dengan harapan yang kemudian terjadi ialah konfirmasi harapan (simple disconfirmation/non-satification). Situasi ini terjadi jika kinerja merek, produk, atau pemasok tertentu, menyamai harapan kinerja yang rendah sehingga hasilnya bukanlah kepuasan atau ketidakpuasan. Istilah non-satisfication juga dapat dipakai untuk menggambarkan keadaan ini, di mana pelanggan merasa tak merasa kecewa dan juga tidak akan melakukan komplain.

\section{Equity Theory}

Berdasarkan teori ini, perasaan tidak puas disebabkan keyakinan bahwa norma sosial telah dilanggar. Dalam teori ini berlaku norma yang menegaskan bahwa setiap pihak dalam pertukaran harus mendapat perlakuan adil atau fair. Jadi, kepuasan terjadi jika rasio hasil dan input setiap pihak dalam pertukaran kurang lebih sama. Sebaliknya, ketidakpuasan terjadi jika pelanggan meyakini bahwa rasio hasil dan inputnya lebih jelek ketimbang perusahaan atau penyedia jasa. Selain itu, kepuasan pelanggan atas transaksi dipengaruhi oleh perbandingan dengan rasio hasil dan input pelanggan lain. Dengan demikian, evaluasi terkait keadilan keseluruhan (overall equity) pada transaksi pembelian sebuah produk sangat berpengaruh terhadap kepuasan/ketidakpuasan pelanggan. 


\section{Attribution Theory}

Teori ini mengidentifikasi proses yang dilakukan seseorang dalam menentukan penyebab aksi/tindakan dirinya, orang lain dan objek tertentu. Atribusi mampu memengaruhi kepuasan purnabeli seseorang terhadap produk atau jasa tertentu karena atribusi memoderasi perasaan puas atau tidak puas.

\section{Assimilation-Contrast Theory}

Menurut teori ini, konsumen mungkin menerima penyimpangan (deviasi) dari ekspektasinya dalam batas tertentu. Apabila produk atau jasa yang dibeli serta dikonsumsi tidak terlalu berbeda dengan apa yang diharapkan pelanggan maka kinerja produk/jasa tersebut akan diasimilasi/diterima dan produk atau jasa itu dievaluasi secara positif (dinilai memuaskan). Akan tetapi, jika kinerja produk atau jasa malah melampaui zona penerimaan konsumen (zone of acceptance), perbedaan yang ada akan dikontraskan sedemikian rupa sehingga akan tampak lebih besar dari sesungguhnya. Setiap pelanggan berbeda-beda dalam toleransi terhadap penyimpangan dari kinerja yang diharapkannya, sedangkan sebagian konsumen lebih toleran dibandingkan dengan konsumen lainnya.

\section{Opponent Process Theory}

Teori ini ingin menjelaskan kenapa pengalaman konsumen yang pada mulanya sangat memuaskan kemudian cenderung dievakuasi kurang memuaskan pada kejadian atau kesempatan berikutnya. Dasar pemikirannya adalah pandangan bahwa organisme akan beradaptasi dengan stimulus di lingkungannya sehingga stimulus berkurang intensitasnya sepanjang waktu.

\section{Merek (Brand)}

Menurut Aaker (dalam Rangkuti, 2009: 36), merek merupakan nama atau simbol yang bersifat membedakan (seperti logo, cap, kemasan) dan bertujuan agar bisa mengidentifikasi barang/jasa dari seorang penjual/kelompok penjual tertentu. Dengan demikian, suatu merek memberi pembeda terhadap barang atau jasa yang dihasilkan oleh kompetitor.

Menurut Tjiptono (2015: 187) merek cenderung diinterpretasikan berbeda, seperti sebagai tanda kepemilikan, alat fungsional, alat simbolis, shorthand device, risk reducer, legal device, dan stratgic device. Dari banyaknya pengertian tentang merek, definisi merek yang paling banyak diacu adalah versi American Marketing Association (AMA) yang merumuskan merek sebagai nama, istilah, tanda, simbol, atau desain, atau kombinasi di antaranya yang bertujuan mengidentifikasi barang dan jasa dari satu penjual/sekelompok penjual dan menjadi pembeda dari barang atau jasa para pesaingnya. Definisi versi AMA ini juga digunakan dalam Undang- 
Undang Merek Nomor 15 Tahun 2001 Pasal 1 Ayat 1: tanda yang berupa gambar, nama, huruf-huruf, angka-angka, susunan warna, atau kombinasi dari unsur-unsur tersebut yang memiliki daya pembeda dan digunakan dalam kegiatan perdagangan barang atau jasa.

Bagi produsen, merek berperan penting sebagai sarana menciptakan suatu asosiasi dan makna unik (diferensiasi), sarana keunggulan kompetitif, dan sumber financial returns. Bagi konsumen, merek berperan sebagai identifikasi produk dan jasa, penetapan tanggung jawab pada produsen/distributor spesifik, pengurangan risiko, penekanan biaya pencarian internal dan eksternal, janji atau ikatan khusus dengan produsen, alat simbolis yang memproyeksikan citra diri dan signal kualitas.

Dalam kaitannya dengan strategi merek, Kotler (dalam Rangkuti, 2009: 37-38) menjelaskan bahwa strategi merek dapat terkait dengan empat hal berikut ini. Pertama, merek baru (new brand), yaitu di mana perusahaan menciptakan sebuah merek baru sewaktu memasuki kategori produk baru. Strategi ini dapat dilakukan karena tidak ada nama merek yang sesuai. Kedua, perluasan merek (multi brand). Perusahaan ingin mengelola berbagai nama merek dalam kategori yang ada untuk mengemukakan fungsi dan manfaat yang berbeda. Ketiga, perluasan merek (brand extension), yaitu menggunakan nama merek yang telah berhasil guna meluncurkan produk baru atau yang dimodifikasi dalam kategori baru. Keempat, perluasan lini (line extension), yaitu strategi yang dilakukan dengan cara memperkenalkan berbagai macam feature atau tambahan variasi produk dalam sebuah produk yang ada di bawah nama merek yang sama, misalnya rasa, bentuk, warna, atau kemasan baru

\section{Ekuitas Merek (Brand Equity)}

Menurut Aaker (dalam Rangkuti, 2009) ekuitas merek adalah seperangkat aset serta liabilitas merek yang terkait dengan suatu merek nama dan simbol yang dapat menambah atau mengurangi nilai yang diberikan oleh sebuah produk/ jasa, baik pada perusahaan ataupun pada pelanggan. Selain dapat memberi nilai kepada konsumen, ekuitas merek juga memberikan nilai pada perusahaan dalam berbagai bentuk berikut ini.

1. Mempertinggi keberhasilan program dalam mengikat konsumen baru sekaligus merangkul kembali konsumen lama. Promosi yang dilakukan bisa lebih efektif apabila merek sudah dikenal. Ekuitas merek yang kuat tidak bisa menghalangi keraguan konsumen terhadap kualitas merek.

2. Empati dimensi ekuitas merek (kesadaran merek, kesan merek beserta asosiasiasosiasinya) dapat memengaruhi alasan pembelian konsumen. 
3. Kesetiaan merek yang telah diperkuat merupakan hal penting dalam merespon inovasi yang dilakukan para pesaing.

4. Asosiasi merek sangat penting, baik sebagai dasar strategi positioning maupun strategi perluasan produk. Suatu analisis atas porfolio merek sangat diperlukan untuk mengetahui efektifitas dari perluasan merek yang telah dilakukan.

5. Salah satu cara memperkuat ekuitas merek adalah dengan melakukan promosi secara besar-besaran yang membutuhkan biaya besar. Ekuitas merekyang kuat memungkinkan perusahaan memperoleh laba yang lebih tinggi.

6. Ekuitas merek yang kuat bisa digunakan sebagi dasar untuk pertumbuhan dan perluasan merek kepada produk lainnya, atau menciptakan peluang bisnis baru yang terkait yang biayanya akan lebih mahal tanpa mempunyai ekuitas merek tersebut.

7. Ekuitas merek yang kuat meningkatkan penjualan karena mampu menciptakan loyalitas seluruh distribusi. Produk dengan ekuitas merek yang kuat akan dicari oleh pedagang karena akan memberikan keuntungan.

8. Aset-aset ekuitas merek lainnya bisa memberikan keuntungan kompetitif bagi perusahaan dengan memanfaatkan celah-celah yang tak dimiliki oleh pesaing. Pada umumnya orang tak ragu lagi terhadap perusahaan yang memiliki ekuitas merek yang kuat sehingga kepercayaan untuk memasarkan produknya semakin meningkat.

\section{METODE PENELITIAN}

Penelitian ini menggunakan paradigma positivisme dengan pendekatan kuantitatif. Sebagai penelitian deskriptif dan menggunakan causal explanations, penelitian ini ingin mengetahui hubungan sebab-akibat di antara dua variabel atau lebih. Dalam penelitian kausal ini peneliti hendak menjelaskan pengaruh perubahan variasi nilai dalam suatu variabel terhadap perubahan variasi nilai pada satu atau lebih variabel lainnya. Artinya, apakah perubahan nilai dalam suatu variabel disebabkan adanya perubahan nilai dalam variabel yang lainnya. Populasi dalam penelitian ini adalah pelanggan Batik Air yang berada di ruang tunggu keberangkatan domestik Terminal 1C Bandar Udara Internasional Soekarno-Hatta Jakarta sebab mempunyai kriteria target audiens utama sebagai pengguna jasa layanan transportasi udara Batik Air. Jumlah populasi dalam penelitian ini ialah 978 orang dengan responden 120 orang yang diambil dengan teknik probability sampling secara acak sederhana. Sumber data penelitian diperoleh lewat kuesioner yang didesain dengan teknik skala likert. 
Dalam penelitian ini, yang menjadi variabel independen adalah Pelayanan Prima $(X)$, yang terdiri dari: bukti fisik atau tangibles $\left(\mathrm{X}_{1}\right)$; kendalan atau reability $\left(\mathrm{X}_{2}\right)$; daya tanggap atau responsiveness $\left(\mathrm{X}_{3}\right)$; jaminan $\left(\mathrm{X}_{4}\right)$; empati $\left(\mathrm{X}_{5}\right)$. Sementara variabel dependen $(\mathrm{Y})$ dalam penelitian ini ialah Ekuitas Merek yang mempunyai empat dimensi: kesadaran merek; kesan merek; persepsi pelanggan; dan kesetiaan merek.

\section{HASIL DAN PEMBAHASAN \\ Penyajian Data}

Pada pelaksanaan survei, peneliti menyebarkan kuesioner kepada 120 responden, dan hasil yang diperoleh adalah 120 kuesioner yang sah. Pengumpulan kuesioner dilakukan dengan membagikan kuesioner secara simple random sampling lantaran dilakukan secara acak tanpa memperhatikan strata dalam populasi. Peneliti tidak membedakan jumlah responden yang ada di ruang bussiness class dan economy class. Karena itu, 120 kuesioner yang terkumpul tersebut dikatakan sah.

Penelitian ini dilakukan pada pelanggan/pengguna jasa penerbangan Batik Airlines dengan rentang usia 18-60 tahun: jumlah responden berjenis kelamin laki-laki sebanyak 80 pelanggan $(66,67 \%)$ dan jumlah responden berjenis perempuan sebanyak 40 pelanggan (33,33\%). Dominannya responden berjenis kelamin laki-laki disebabkan banyaknya yang bepergian untuk bekerja dan berlibur ke berbagai tujuan wisata serta kembali ke kota asal pelanggan, sementara untuk jenis kelamin perempuan sebagian besar bepergian dengan tujuan bekerja di Jakarta dan pulang ke tempat asalnya.

Sementara itu, jumlah responden terbanyak berdasarkan pengelompokkan usia ialah responden dengan rentang usia 18-22 tahun sebanyak 17 responden atau 14,17\%, usia 23 27 tahun sebanyak 47 responden atau 39,17\%, rentang usia 28-32 tahun sebanyak 41 responden atau 34,17\%, rentang usia 33-37 sebanyak 11 orang atau 9,17\%, dan usia 38 tahun ke atas sebanyak 4 responden atau 3,33\%.

\section{Lama Responden menjadi Pelanggan}

Dalam penelitian ini lama menjadi responden tidak berperan sebagai variabel pada hubungan bivariat atau multivariat, tetapi hanya digunakan untuk menggambarkan responden penelitian berdasarkan psikografis. Jumlah responden yang memakai jasa penerbangan Batik Air kurang dari 3 bulan sebanyak 31 responden (38,75\%), 2-4 bulan sebanyak 18 responden (22,50\%), 7-9 bulan sebanyak 8 orang $(10,00 \%), 10-12$ bulan sebanyak 6 responden $(7,50 \%)$, dan lebih dari satu tahun sebanyak 17 responden $(21,25 \%)$. 


\section{Intensitas Kunjungan Responden}

Intensitas kunjungan responden dikelompokkan berdasarkan frekuensi responden bepergian secara berkala. Intensitas kunjungan pelanggan dibagi menjadi setiap 1-2 minggu sebanyak 10,00\%, 2-4 minggu sekali sebanyak 7,50\%, 1-2 bulan sekali sebanyak 12,50\%, 23 bulan sekali sebanyak $23,33 \%$, lebih dari $3-4$ bulan sebanyak $46,67 \%$.

\section{Uji Instrumen Data}

Uji Validitas

Tabel 1. Pengukuran KMO Pelayanan Prima dan Ekuitas Nilai

\begin{tabular}{|c|c|c|c|c|c|}
\hline No & Dimensi Variabel & $\begin{array}{c}\text { Nilai KMO Measure of } \\
\text { Sampling Adequency / } \\
\mathrm{r}_{\text {hitung }}\end{array}$ & Sig. & $r_{\text {tabel }}$ & Kriteria \\
\hline 1 & Dimensi Bukti Fisik & 0,807 & 0,000 & 0,181 & Valid \\
\hline 2 & Dimesi Keandalan & 0,741 & 0,000 & 0,181 & Valid \\
\hline 3 & $\begin{array}{l}\text { Dimensi Daya } \\
\text { Tanggap }\end{array}$ & 0,670 & 0,000 & 0,181 & Valid \\
\hline 4 & Dimensi Jaminan & 0,880 & 0,000 & 0,181 & Valid \\
\hline 5 & Dimensi Empati & 0,730 & 0,000 & 0,181 & Valid \\
\hline No & Dimensi Variabel & $\begin{array}{c}\text { Nilai KMO Measure of } \\
\text { Sampling Adequency / } \\
r_{\text {hitung }}\end{array}$ & Sig. & $r_{\text {tabel }}$ & Kriteria \\
\hline 1 & $\begin{array}{l}\text { Dimensi Kesadaran } \\
\text { Merek }\end{array}$ & 0,629 & 0,000 & 0,181 & Valid \\
\hline 2 & Dimensi Kesan Merek & 0,712 & 0,000 & 0,181 & Valid \\
\hline 3 & Dimensi Kualitas Merek & 0,788 & 0,000 & 0,181 & Valid \\
\hline 4 & Dimensi Loyalitas Merek & 0,500 & 0,000 & 0,181 & Valid \\
\hline
\end{tabular}

Sumber: Hasil Pengolahan data menggunakan SPSS 23 For Windows.

Berdasarkan Tabel 1 dan 2 di atas maka bisa dilihat bahwa semua dimensi untuk pelayanan prima dan ekuitas nilai memiliki status valid sebab nilai KMO Measure of Sampling Adequency $/ r_{\text {hitung }}>r_{\text {tabel }}$ sebesar 0,181.

\section{Uji Reliabilitas}

Uji reliabilitas pada penelitian ini menggunakan koefisien Alpha Croanbach. Nilai Alpha yang diperoleh menunjukkan konsistensi indikator yang digunakan. Sebuah indikator dianggap relaible apabila mempunyai nilai Alpha Croanbach $>0,5$. Jika nilai Alpha Croanbach $<0,5$ maka indikator yang digunakan kurang reliable. 
Tabel 2. Uji Reliabilitas Dimensi Penelitian

\begin{tabular}{|c|c|c|c|}
\hline No & Dimensi Penelitian & Nilai Croanbach's Alpha & Keterangan \\
\hline \multicolumn{4}{|c|}{ Variabel Pelayanan Prima } \\
\hline 1 & Dimensi Bukti Fisik & 0,826 & Sangat Tinggi \\
\hline 2 & Dimensi Keandalan & 0,747 & Tinggi \\
\hline 3 & Dimensi Daya Tanggap & 0,768 & Tinggi \\
\hline 4 & Dimensi Jaminan & 0,914 & Sangat Tinggi \\
\hline 5 & Dimensi Empati & 0,825 & Tinggi \\
\hline \multicolumn{4}{|c|}{ Variabel Ekuitas Merek } \\
\hline 1 & Dimensi Kesadaran Merek & 0,729 & Tinggi \\
\hline 2 & Dimensi Asosiasi Merek & 0,806 & Tinggi \\
\hline 3 & Dimensi Kesan Kualitas & 0.830 & Sangat Tinggi \\
\hline 4 & Dimensi Loyalitas Merek & 0.800 & Tinggi \\
\hline
\end{tabular}

Sumber: Hasil Pengolahan data menggunakan SPSS 23 for Windows.

Berdasarkan tabel di atas dapat diketahui bahwa hasi Uji Reliabilitas untuk seluruh dimensi dalam variabel yang digunakan dalam penelitian ini memiliki nilai Alpha Croanbach's $>0.05$, yang berarti keseluruhan indikator yang digunakan untuk mengukur setiap dimensi dalam variabel penelitian ini sudah reliable.

\section{Metode Analisis Data}

\section{Metode Analisis Bivariat}

Dalam penelitian ini, terdapat dua hipotesis. Pertama, dengan menggunakan nilai signifikansi yang terdapat pada tabel regresi linear. Batas nilai signifikansi yang digunakan untuk menguji hipotesis adalah 0.05. Jika nilai signifikansi berada di bawah 0.05 maka Ho ditolak, sedangkan jika nilai signifikansi berada di atas 0.05 maka Ha diterima.

Tabel 3. Nilai Uji Analisis Bivariat Pearson's Correlations

\begin{tabular}{clcc}
\hline No & Dimensi Variabel & $\begin{array}{c}\text { Nilai Pearson's } \\
\text { Correlations }\end{array}$ & Kriteria \\
\hline 1 & Dimensi Bukti Fisik & 0,357 & Cukup Kuat \\
2 & Dimensi Keandalan & 0,362 & Kuat \\
3 & Dimensi Daya Tanggap & 0,195 & Cukup Kuat \\
4 & Dimesi Jaminan & 0,401 & Kuat \\
5 & Dimensi Empati & 0,534 & Kuat \\
\hline
\end{tabular}


Selanjutnya, untuk mengetahui dimensi yang paling mempunyai kekuatan pengaruh atau memberikan sumbangan terbesar terhadap ekuitas nilai bisa dilihat pada tabel berikut ini.

Tabel 4. Nilai Regresi Ganda dari Dimensi Pelayanan Prima terhadap Ekuitas Nilai

\begin{tabular}{clcc}
\hline No & Dimensi Variabel & Nilai $\mathbf{R}_{\text {square }}$ & Kriteria \\
\hline 1 & Dimensi Bukti Fisik & 0,357 & Lemah \\
2 & Dimensi Keandalan & 0,362 & Lemah \\
3 & Dimensi Daya Tanggap & 0,195 & Sangat Lemah \\
4 & Dimesi Jaminan & 0,401 & Cukup Kuat \\
5 & Dimensi Empati & 0,534 & Cukup Kuat \\
\hline
\end{tabular}

Sumber: Hasil Pengolahan data menggunakan SPSS 23 for Windows.

Dari tabel diatas, terlihat bahwa dimensi empati memiliki pengaruh yang besar terhadap terbentuknya ekuitas nilai pelanggan Batik Air dibanding dengan dimensi lainnya,dan diikuti dengan dimensi jaminan, dimensi keandalan, dimensi bukti fisik dan tanggung jawab.

\section{Hipotesis Penelitian}

Uji Signifikansi Pengaruh Parsial (Uji T)

Tabel 5. Nilai Koefisien Regresi Linear

Coefficients $^{\mathrm{a}}$

\begin{tabular}{|c|c|c|c|c|c|c|}
\hline \multirow{2}{*}{\multicolumn{2}{|c|}{ Model }} & \multicolumn{2}{|c|}{$\begin{array}{c}\text { Unstandardized } \\
\text { Coefficients }\end{array}$} & \multirow{2}{*}{$\begin{array}{c}\text { Standardized } \\
\text { Coefficients } \\
\text { Beta }\end{array}$} & \multirow[b]{2}{*}{$\mathrm{t}$} & \multirow[b]{2}{*}{ Sig. } \\
\hline & & $B$ & Std. Error & & & \\
\hline \multirow[t]{6}{*}{1} & (Constant) & 16,773 & 2,780 & & 6,034 & ,000 \\
\hline & Bukti Fisik & 199 & 185 & ,125 & 1,072 & 286 \\
\hline & Keandalan & ,281 & ,255 & 114 & 1,099 & 274 \\
\hline & Daya Tanggap &,- 766 & ,343 &,- 219 & $-2,230$ & ,028 \\
\hline & Jaminan & ,218 & 127 & 198 & 1,718 & ,089 \\
\hline & Empati & 1,121 & ,215 & ,552 & 5,209 & ,000 \\
\hline
\end{tabular}

a. Dependent Variable: Ekuitas Nilai

Sumber: Hasil Pengolahan data menggunakan SPSS 23 for Windows 
Persamaan regresi di atas dapat dijelaskan sebagai berikut ini.

1. Nilai konstanta sebesar 16,773 . Artinya, jika X1 - X5 nilainya adalah 0 maka nilai ekuitas nilai $(Y)$ sebesar 16,773 .

2. Koefisiensi regresi variabel bukti fisik $\left(X_{1}\right)$ sebesar 0,199 . Artinya, jika variabel independen lain nilainya tetap dan bukti fisik mengalami kenaikan $1 \%$ maka nilai ekuitas nilai (Y) akan mengalami peningkatan sebasar $1,99 \%$. Koefisien bernilai positif artinya terjadi hubungan positif terhadap bukti fisik dan ekuitas nilai.

3. Koefisen regresi variabel keandalan $\left(\mathrm{X}_{2}\right)$ sebesar 0,281 . Artinya, jika variabel independen lain nilainya tetap dan keandalan mengalami kenaikan $1 \%$, ekuitas nilai $(Y)$ mengalami peningkatan sebesar $2,81 \%$. Koefisien bernilai positif yang artinya terjadi hubungan positif terhadap keandalan dan ekuitas nilai.

4. Koefisen regresi variabel daya tanggap $\left(X_{3}\right)$ ialah sebesar -0,766. Artinya, jika variabel independen lain nilainya tetap dan daya tanggap mengalami penurunan $1 \%$ maka ekuitas nilai (Y) akan mengalami penurunan sebesar $7,66 \%$. Koefisien bernilai negatif yang artinya terjadi hubungan negatif terhadap daya tanggap dan ekuitas nilai.

5. Koefisen regresi variabel jaminan $\left(X_{4}\right)$ sebesar 0,218 . Artinya apabila variabel independen yang lain nilainya tetap dan jaminan mengalami kenaikan $1 \%$ maka ekuitas nilai (Y) akan mengalami peningkatan sebesar $2,18 \%$. Koefisien bernilai positif. Artinya, terjadi hubungan positif terhadap keandalan dan ekuitas nilai.

6. Koefisen regregsi variabel empati $\left(X_{5}\right)$ sebesar 1,121. Artinya apabila variabel independen yang lain nilainya tetap dan empati mengalami kenaikan $1 \%$ maka ekuitas nilai (Y) akan mengalami peningkatan yaitu sebesar $11,21 \%$. Koefisien bernilai positif. Artinya, terjadi hubungan positif terhadap empati dan ekuitas nilai.

\section{Koefisien Determinasi (R2)}

Koefisensi determinasi bertujuan guna mengetahui seberapa besar variasi perubahan dalam satu variabel (dependen) ditentukan oleh perubahan dalam variabel lainnya (independen). Dalam konteks ini, koefiesiensi determinasi merupakan kuadrat dari koefisien korelasi $\left(R^{2}\right)$. 
Tabel 6. Hasil Korelasi Ganda antara Pelayanan Prima terhadap Ekuitas Nilai

\begin{tabular}{|c|c|c|c|c|}
\hline \multicolumn{5}{|c|}{ Model Summary } \\
\hline Model & $\mathrm{R}$ & R Square & $\begin{array}{l}\text { Adjusted R } \\
\text { Square }\end{array}$ & $\begin{array}{l}\text { Std. Error of } \\
\text { the Estimate }\end{array}$ \\
\hline 1 & $758^{a}$ & ,575 & ,556 & 4,560 \\
\hline
\end{tabular}

a. Predictors: (Constant), Empati, Daya Tanggap,

Keandalan, Jaminan, Bukti_Fisik

Sumber: Hasil Pengolahan data SPSS 23 for Windows.

Berdasarkan tabel di atas diperoleh angka $R^{2}$ ( $R$ Square) sebesar 0,575 atau (57,5\%). Hal ini memperlihatkan bahwa presentase sumbangan pengaruh variabel independen $\left(X_{1}-X_{5}\right)$ terhadap variabel dependen ekuitas nilai $(Y)$ sebesar $57,5 \%$. Atau variasi variabel independen yang digunakan dalam model $\left(X_{1}-X_{5}\right)$ mampu menjelaskan sebesar $57,5 \%$ variasi variabel dependen ekuitas nilai (Y). Adapun sisanya sebesar 42,5\% dipengaruhi atau dijelaskan oleh variabel lainnya yang tidak dimasukkan dalam model penelitian ini.

\section{Uji Signifikansi Simultan (Uji F)}

Uji F digunakan untuk mengetahui tingkat signifikansi pengaruh-pengaruh variabel independen secara bersama-sama (simultan) terhadap variabel dependen.

Tabel 7. Uji Signifikansi Simultan (Uji F)

\begin{tabular}{|c|c|c|c|c|c|c|}
\hline \multicolumn{7}{|c|}{ ANOVA $^{a}$} \\
\hline \multicolumn{2}{|c|}{ Model } & $\begin{array}{l}\text { Sum of } \\
\text { Squares }\end{array}$ & $d f$ & $\begin{array}{l}\text { Mean } \\
\text { Square }\end{array}$ & $\mathrm{F}$ & Sig. \\
\hline \multirow[t]{3}{*}{1} & Regression & 3204,818 & 5 & 640,964 & 30,830 &, $000^{b}$ \\
\hline & Residual & 2370,107 & 114 & 20,790 & & \\
\hline & Total & 5574,925 & 119 & & & \\
\hline
\end{tabular}

a. Dependent Variable: Ekuitas_Nilai

b. Predictors: (Constant), Empati, Tanggung_Jawab, Keandalan, Jaminan, Bukti_Fisik

Sumber: Hasil Pengolahan data SPSS 23 for Windows. 
Pada tabel di atas, pengujian secara simultan pelayanan prima $\mathrm{X}_{1}, \mathrm{X}_{2}, \mathrm{X}_{3}, \mathrm{X}_{4}, \mathrm{X}_{5}$, terhadap Ekuitas Nilai (Y), dari tabel di atas diperoleh nilai $\mathrm{F}_{\text {hitung }} 30,830$ dengan nilai probabilitas (sig) $=0,00$. Nilai $F_{\text {hitung }}(30,830)>F_{\text {tabel }}(2.29)$ dan nilai signifikansi $<0,05$ tersebut menunjukkan terdapat pengaruh yang signifikan dari pelayanan prima terhadap ekuitas nilai, yang berarti Ho ditolak dan Ha diterima.

\section{Pelayanan Prima}

Perlakuan baik terhadap pelanggan dapat membentuk citra positif di dalam benak pelanggan terhadap citra perusahaan. Citra perusahaan sendiri mempunyai kedudukan yang penting karena dapat memengaruhi persepsi pelanggan terhadap kualitas produk/jasa yang ditawarkan perusahaan. Apabila penyedia jasa memiliki citra positif dalam benak pelanggannya, maka pelanggan akan mudah memaafkan kesalahan kecil yang terjadi.

Selain itu, kualitas produk atau jasa juga dapat meningkatkan kemampuan perusahaan dalam mempertahankan pelanggan yang kemudian dapat berkontribusi pada loyalitas pelanggan, ekuitas pelanggan, dan profitabilasi perusahaan. Karena itu, pelayanan yang diberikan harus dengan standar pelayanan prima, dan standar pelayanan prima tersebut perlu dipatuhi oleh setiap karyawan yang terlibat sesuai dengan bidang tugasnya masingmasing, khususnya dalam bidang pelayanan jasa penerbangan yang sarat persaingan (Adhitama, Kusumawati dan Abdillah, 2017; Aryani \& Rosinta, 2010; Wendha, Rahyuda \& Suasana, 2013; Kurnia \& Suwikno, 2018; Boavida, 2017).

\section{Ekuitas Nilai}

Program pelayanan prima yang diterapkan oleh Batik Air bertujuan untuk membina hubungan dengan pelanggannya. Dalam hal ini proses yang berlangsung lebih banyak berhubungan dengan masalah psikologis dan perilaku konsumen itu sendiri. Dengan melihat perilaku konsumen sewaktu memutuskan untuk membeli, manajer pemasaran mampu menentukan seberapa jauh persepsi brand equity yang dimiliki oleh pelanggan terhadap Batik Air. Sementara itu, persyaratan agar dapat masuk ke tahap perkembangan yang lebih tinggi adalah pelanggan harus memiliki komitmen terhadap merek tersebut atau minimal pelanggan telah mengekspresikan dirinya sendiri dengan menggunakan merek tersebut (Baraba \& Anggraeni, 2008; Roring, 2012; Utamaningsih, 2005; Widyastuti dan Zainuddin, 2015; Darmawan, 2007; Rizky \& Pantawis, 2011; Basit \& Rahmawati, 2017).

Pendekatan yang digunakan pun harus hati-hati, karena tidak semua merek harus melalui tahapan yang sama. Suatu merek dapat saja meloncat dari satu tahap ke tahap lainnya. Namun, manfaat yang diperoleh dari model tersebut adalah kita dapat mengetahui secara 
jelas perubahan apa yang harus dilakukan dalam rangka memenuhi keinginan pelanggan yang terus menerus berubah.

Model ini juga dapat menjelaskan perbedaan penerapan strategi penciptaan suatu merek pada masing-masing kategori produk/jasa. Adapun perubahan strategi yang diperlukan dipengaruhi oleh beberapa faktor, antara lain keahlian yang sudah dimiliki oleh manajemen, tujuan strategis perusahaan, target pemasaran, kekuatan merek perusahaan pesaing, selera konsumen, tingkat keterlibatan pelanggan atau perusahaan dalam produk/jasa, product life cycle dan posisi pengembangan merek dalam masing-masing kategori produk/jasa yang relevan (Rangkuti, 2009: 33-35).

\section{Pengaruh Pelayanan Prima Terhadap Ekuitas Nilai}

Untuk mengetahui variabel independen $(X)$ mana yang memiliki pengaruh nyata terhadap variabel dependen $(Y)$, berikut ini akan dijelaskan secara terperinci sehingga akan didapat gambaran yang memadai. Kelima variabel independen $(X)$ yang digunakan dalam penelitian ini adalah: bukti fisik, keandalan, daya tanggap, jaminan, empati.

Berdasarkan hasil pengaruh bukti fisik terhadap ekuitas nilai terlihat bahwa $\mathrm{T}_{\text {hitung }}(1,072)$ $>T_{\text {tabel }}(1,658)$, yang berarti bahwa hipotesis penelitian ini ditolak. Artinya, tidak terdapat pengaruh signifikan antara bukti fisik terhadap ekuitas nilai Batik Air. Jadi, semakin baik bukti fisik yang mampu menciptakan rasa aman dan nyaman pada pelanggan, maka semakin tinggi pula pengaruhnya terhadap ekuitas nilai Batik Air di dalam benak pelanggannya.

Pada hasil pengujian hipotesis kedua, pengaruh keandalan terhadap ekuitas nilai, terlihat bahwa $T_{\text {hitung }}(1,099)>T_{\text {tabel }}(1,658)$ yang berarti hipotesis penelitian ini ditolak. Artinya, tidak terdapat pengaruh signifikan antara keandalan terhadap ekuitas nilai Batik Air. Sementara pada hasil pengujian hipotesis ketiga, pengaruh daya tanggap terhadap ekuitas nilai terlihat bahwa $T_{\text {hitung }}(-2230)>T_{\text {tabel }}(1,658)$, yang artinya hipotesis penelitian ini ditolak. Dapat dikatakan bahwa tidak terdapat pengaruh signifikan antara daya tanggap terhadap ekuitas nilai Batik Air. Artinya, daya tanggap yang diberikan karyawan Batik Air terhadap pelanggan belum dapat menangani kebutuhan pelanggan dengan pelayanan yang prima. Rendahnya rata-rata dimensi daya tanggap menunjukkan bahwa daya tanggap karyawan, terutama pemberian pelayanan secara cepat, menjadi poin utama yang perlu diperbaiki guna mewujudkan pelayanan prima di maskapai penerbangan Batik Air (Rahayu, 2014).

Pada dimensi berikutnya (jaminan) hasil pengujian memperlihatkan bahwa $T_{\text {hitung }}(1,178)$ $>T_{\text {tabel }}(1,658)$, yang berarti hipotesis penelitian ini ditolak. Dengan demikian, tidak ada pengaruh signifikan antara dimensi jaminan terhadap ekuitas nilai Batik Air. Hal ini menunjukkan bahwa jaminan yang diberikan oleh maskapai Batik Air belum memadai. Adapun 
pada hasil pengujian hipotesis kelima (dimensi empati) terlihat $T_{\text {hitung }}(5.209)>T_{\text {tabel }}(1,658)$, yang berarti hipotesis penelitian ini diterima. Jadi, terdapat pengaruh signifikan antara dimensi empati terhadap ekuitas nilai Batik Air yang memperlihatkan tercapainya dimensi empati dalam pelayanan yang diberikan oleh maskapai Batik Air kepada pelangganya. Pengaruh empati ini juga sudah banyak dibuktikan dalam berbagai penelitian lainnya, di mana hasilnya menunjukkan pentingnya peran empati bagi peningkatan ekuitas nilai perusahaan (Harianto \& Subagio, 2013; Primananda \& Setiawan, 2014; Wardhani, 2006; dan Susanto, 2012).

\section{PENUTUP}

\section{Kesimpulan}

Setelah melakukan pengujian, analisis, dan pembahasan terhadap data penelitian, peneliti membuat beberapa kesimpulan yang bertujuan untuk menjawab hipotesis dan pertanyaan penelitian yang diajukkan sebelumnya.

1. Berdasarkan pernyataan yang diberikan oleh responden terhadap pelayanan prima yang diterapkan perusahaan Batik Air di Bandara Internasional Soekarno-Hatta, Cengkareng selama periode Agustus - Oktober 2016, pelayanan prima berada pada kategori penilaian tinggi. Penilaian tertinggi berada pada dimensi empati, sementara penilaian terendah terletak pada dimensi daya tanggap.

2. Berdasarkan dari data hasil model summary koefisien determinasi diperoleh angka sebesar (57,5\%). Nilai tersebut dapat digunakan untuk melihat besarnya hubungan variabel bukti fisik, keandalan, daya tanggap, jaminan, dan empati dengan equitas nilai. Koefisien determinasi tersebut memiliki maksud bahwa hubungan variabel independen (secara keseluruhan) dengan variabel dependen ialah sebesar $57,5 \%$, sementara sisanya sebesar $42,5 \%$ dipengaruhi faktor lainnya yang tidak diteliti dalam penelitian ini.

\section{Saran}

Hasil penelitian ini menunjukkan bahwa pelayanan prima punya pengaruh yang signifikan terhadap ekuitas nilai. Lantaran penelitian ini hanya menggunakan instrumen kuesioner dengan model pertanyaan tertutup, peneliti selanjutnya dapat mengembangkan/ mengombinasikan dengan penggunaan pertanyaan terbuka untuk mengetahui alasan responden secara menyeluruh di balik penilaian yang diberikan. Meskipun pelayanan prima yang diterapkan maskapai Batik Air telah memberikan kontribusi positif dalam bentuk ekuitas nilai, namun masih terdapat hal lain yang perlu diperbaiki, terutama terkait banyaknya keluhan 
pelanggan Batik Air terhadap pelayanan yang lambat sehingga membuat pelanggan menunggu. Selain itu, Batik Air juga dapat lebih mengantisipasi antrian pelanggan dengan cara menambahkan beberapa tambahan tempat chek in counter dan tambahan karyawan supaya tidak menyebabkan antrian yang begitu padat.

\section{REFERENSI}

Adhitama, Radhitya, Andriani Kusumawati, dan Yusri Abdillah. (2017). "The Influence of Service Quality on Brand Image and Customer Satisfaction in Airlines Services (Survey of The Garuda Indonesia Passenger Domiciled in Malang, East Java)". Jurnal Administrasi Bisnis (JAB), 23(1): 122-130.

Aryani, Dwi dan Febrina Rosinta. (2010). "Pengaruh Kualitas Layanan terhadap Kepuasan Pelangga dalam Membentuk Loyalitas Pelanggan, Bisnis \& Birokrasi". Jurnal IImu Administrasi dan Organisasi, 17(2): 114-126.

Azmarani, Adinda Wahyu. (2016). “Analisis Kualitas Pelayanan Maskapai Penerbangan Low Cost Carrier (Studi Deskriptif Di PT. Citilink Indonesia Cabang Surabaya)". Kebijakan dan Manajemen Publik, 4(3): 1-9.

Baraba, Ridwan dan Indah Dwi Anggraeni. (2008). "Pengaruh Brand Equity Sepeda Motor terhadap Kepuasan Konsumen". Segmen (Jurnal Manajemen dan Bisnis), 2: 41-59.

Basit, Abdul dan Tri Herni Rahmawati. (2017). “Cyber Public Relations (E-PR) dalam Brand Image Wardah Kosmetik dengan Pedekatan Mixed Method". Nyimak (Journal of Communication), 1(2): 197-208.

Boavida, Artur Avila de Jesus. (2017). “Pengaruh Kualitas Pelayanan terhadap Kepuasan dan Loyalitas Nasabah Banco Nacional Comercio Timor Leste (BNCTL)". E-Jurnal Ekonomi dan Bisnis Universitas Udayana, 6(11): 3857-3886.

Darmawan, Didit. (2007). "Konseptualisasi Ekuitas Nilai". Jurnal Kewirausahaan, 1(2): 1-9. Harianto, David dan Hartono Subagio. (2013). “Analisa Pengaruh Kualitas Layanan, Brand Image, Dan Atmosfer Terhadap Loyalitas Konsumen Dengan Kepuasan Konsumen Sebagai Variabel Intervening Konsumen Kedai Deja- Vu Surabaya". Jurnal Strategi Pemasaran, 1(1): 1-8.

Kurnia, Marlina dan Suwikno. (2018). “Kepuasan Konsumen: Faktor-faktor yang Mempengaruhi". Balance, 15(1): 111-121.

Lestari, Eristyana Triwi. (2015). "Studi Analisis Loyalitas Konsumen Garuda Indonesia Keberangkatan Jakarta terhadap Brand Garuda Indonesia." Commonline, 4(2): 329-339.

Primananda, Putu Bayu Dewangga dan Putu Yudi Setiawan. (2014). "Pengaruh Dimensi Kualitas Pelayanan Terhadap Kepuasan Konsumen Pada Good Deal Restaurant". E-Jurnal Manajemen Universitas Udayana, 3(3): 770-783. 
Rahayu, Yesi Dewi. (2014). "Presentasi Diri Customer Service Terhadap Loyalitas Nasabah". Jurnal Online Psikologi, 2(2).

Rahmayanti, Nina. (2013). Manajemen Pelayanan Prima. Yogyakarta: Graha Ilmu.

Rangkuti, Freddy. (2009). The Power of Brands. Jakarta: PT. Gramedia Pustaka Utama.

Rizky, Aditya dan Setyo Pantawis. (2011). "Pengaruh Citra dan Sikap Merek terhadap Ekuitas Merek". Dinamika Sosial Ekonomi, 7(12): 181-196.

Roring, Ferdy. (2012). "Analysis Influence Brand Equity and Service Quality to Costumer Satisfaction Users Blackberry Curve 9300 District Sario Manado". Jurnal Teknik Informatika Universitas Sam Ratulangi, 1(1): 1-14.

Saleky, Saul Ronald Jacob. (2017). “Pengaruh Kualitas Layanan terhadap Kepuasan Pelanggan Rute Domestik Garuda Indonesia di Kota Ambon". Minds (Jurnal Manajemen Ide dan Inspirasi), 4(2): 76-92.

Senja, Anggita Muslimah Maulidya Prahara. (1 Februari 2018). Ini 5 Maskapai Nasional di Indonesia Paling Tepat Waktu di Tahun 2017. Diakses dari https://travel.kompas.com/ read/2018/02/01/211500727/ini-5-maskapai-nasional-di-indonesia-paling-tepat-waktu-ditahun-2017

Susanto, Perengki. (2012). “Pengaruh Kualitas Pelayanan Akademik dan Citra Merek Lembaga terhadap Kepuasan Mahasiswa Universitas Negeri Padang". Tingkap, 8(1): 65-77.

Tjiptono, Fàndy. (2015). Stràtegi Pemàsàràn. Yogyakarta: Penerbit Àndi.

Utamaningsih, Arni. (2005). "Brand Equity Sebagai Indikator Kualitas Suatu Produk". Jurnal Akuntansi \& Manajemen, 1(1): 13-24.

Wardhani, Estie Kusuma dan Ibnu Widiyanto. (2006). “Pengukuran Tingkat Kepuasan Konsumen Jasa Penerbangan (Studi Kasus pada Jasa Penerbangan Garuda Indonesia Semarang-Jakarta)". Jurnal Studi Manajemen \& Organisasi, 3(1): 40-63.

Wendha, AA Ayu Atika Paramitha, I Ketut Rahyuda dan I Gst Agung Ketut Gede Suasana. (2013). "Pengaruh Kualitas Layanan terhadap Kepuasan dan Loyalitas Pelanggan Garuda Indonesia di Denpasar". Jurnal Manajemen (Strategi Bisnis dan Kewirausahaan), 7(1): 19-28.

Widjaja, Ezra Laurentia, Adriana Aprilia dan Agung Harianto. (2017). "Analisa Pengaruh Kualitas Layanan terhadap Kepuasan Penumpang Maskapai Penerbangan Batik Air" Jurnal Hospitality dan Manajemen Jasa, 5(2): 118-132.

Widyastuti, Sri dan Zainuddin. (2015). "Pengaruh Kualitas Produk dan Jasa pada Ekuitas Pelanggan di Coffee Toffee Indonesia". Jurnal Siasat Bisnis, 19(2): 84-196. 
